\title{
Level Penambahan Bokashi Kotoran Sapi terhadap Pertumbuhan dan Produksi pada Panen Pertama Rumput Raja (Pennisetum purpureophoides)
}

\author{
Addition Level of Cattle Feces Bokashi on Growth and Production of the First Harvest of \\ King Grass (Pennisetum purpureophoides)
}

\author{
Sadjadi, B. Herlina, dan W. Supendi \\ Fakultas Pertanian Prodi Peternakan Universitas Musi Rawas \\ Jl. Komplek Perkantoran Pemkab MURA Kel. Air kuti I. Lubuklinggau 31628 \\ Koresponden e-mail: sadjadi_71@yahoo.co.id
}

\begin{abstract}
This research aims to determine the rate of manure bokashi addition on growth and production in the first harvest of King grass (Pennisetum purpureophoides). The observed parameters consisted of plant height, number of tillers, fresh weight production, dry weight production, dry matter production. This research method used non factorial Randomized Block Design (RBD), consisting of 6 (six) treatments with 4 (four) replications. As for the treatment performed is P0: Not using manure bokashi (control). P1: 50g / Polybag. P2: 75g / Polybag. P3: 100g / Polybag. P4: 125g / Polybag. and P5: 150g / Polybag. From 6 treatment levels and 4 replications we got 24 experimental units with 3 sample plants each, so the total sample used were 72 experimental units. To know the effect of treatment, the data obtained were analyzed by analysis of variance and real honest difference (RHD) advanced test. Based on the result of research that the level of addition of manure bokashi significantly affect on plant height, number of tillers, fresh weight production, dry weight production and dry material production. The additional level of cow dung bokhasi of 30 tons/ha (P5) was able to give the best effect on all observed variables.
\end{abstract}

Key words: Level, manure Bokhasi, King Grass (Pennisetum purpureophoides).

\begin{abstract}
ABSTRAK
Penelitian ini bertujuan untuk mengetahui level penambahan bokashi kotoran sapi terhadap pertumbuhan dan produksi pada panen pertama rumput raja (Pennisetum purpureophoides). Parameter yang diamati terdiri dari tinggi tanaman, jumlah anakan, produksi berat segar, produksi berat kering, produksi bahan kering. Metode penelitian ini menggunakan Rancangan Acak Kelompok (RAK) non faktorial, terdiri dari 6 (enam) perlakuan dengan 4 (empat) ulangan. adapun perlakuan yang dilakukan adalah P0 : Tidak menggunakan bokashi kotoran sapi (kontrol). P1 : 50g/Polybag. P2 : 75g/Polybag. P3 : 100g/Polybag. P4 : 125g/Polybag. dan P5 : $150 \mathrm{~g} /$ Polybag. Dari 6 taraf perlakuan dan 4 kali ulangan didapat 24 unit percobaan dengan masing masing 3 unit tanaman sampel, sehingga total sampel yang digunakan 72 unit percobaan. Untuk mengetahui pengaruh perlakuan, data yang diperoleh dianalisis dengan analisis sidik ragam dan uji lanjut BNJ. Berdasarkan hasil penelitian bahwa level penambahan bokashi kotoran sapi berpengaruh sangat nyata terhadap tinggi tanaman, jumlah anakan, produksi berat segar, produksi berat kering dan produksi bahan kering. Level penambahan bokhasi kotoran sapi 30 ton/ha (P5) mampu memberikan pengaruh terbaik terhadap semua peubah yang diamati.
\end{abstract}

Kata Kunci : Level, Bokhasi, Rumput Raja (Pennisetum purpureophoides).

\section{PENDAHULUAN}

Rumput unggul seperti rumput raja (Pennisetum purpureophoides) merupakan salah satu hijauan pakan ternak yang sangat diperlukan dan besar manfaatnya bagi pengembangan usaha peternakan khususnya untuk ternak ruminansia dan kelangsungan populasi ternak ruminansia.
Ketersediaan pakan khususnya pakan hijauan baik kualitas, kuantitas maupun kontinuitasnya merupakan faktor yang penting dalam menentukan keberhasilan usaha peternakan ternak ruminansia.

Rumput raja merupakan hasil persilangan antara rumput gajah (Pennisetum purpureum) dengan rumput barja (Pennisetum thypoides). Rumput raja 
adalah tanaman tahunan (perennial), tumbuh tegak membentuk rumpun. Perakarannya dalam, bentuknya mirip dengan tanaman tebu, tingginya 2-4 m dan apabila dibiarkan tumbuh tegak dapat mencapai $7 \mathrm{~m}$, berbatang tebal dan keras. Rumput raja memiliki pertumbuhan yang sangat cepat mengalahkan rumput gajah. Produksi rumput raja sangat tinggi dapat mencapai 1.076 ton rumput segar/ha/tahun (Suyitman et al., 2003).

Umumnya rumput raja yang digunakan di Indonesia adalah rumput yang tumbuh secara liar. Namun untuk peternakan yang relatif besar maka rumput yang digunakan adalah rumput yang sengaja ditanaman atau dipelihara secara khusus. Hal ini dilakukan untuk memenuhi kebutuhan pakan ternak. Rumput-rumputan dipilih karena merupakan tanaman yang produktifitasnya tinggi dan memiliki sifat yang dapat memperbaiki kondisi tanah (Gonggo et al., 2005). Rumput raja merupakan tanaman yang dapat memperbaiki kondisi tanah yang rusak akibat erosi (Sanderson dan Paul, 2008).

Kendala dalam penyediaan pakan hijauan yang berkualitas dan berkelanjutan adalah lahan subur atau produktif untuk penanaman pakan hijauan ternak. Salah satu solusi untuk mengatasi masalah tersebut adalah dengan pemanfaatan lahanlahan marjinal atau kurang produktif dengan pemberian unsur hara yang diperlukan tanaman dengan cara pemupukan yang sesuai dengan kebutuhan tanaman (Fanindi et al., 2005).

Salah satu cara untuk meningkatkan produksi hijauan adalah dengan melakukan pemupukan, sehingga media tanam untuk tanaman menjadi subur dan menghasilkan hijauan yang baik kualitasnya dan tinggi produksinya.
Tola et al. (2007) menyatakan bahwa Pupuk bokashi kotoran sapi merupakan salah satu alternatif dalam penerapan teknologi pertanian organik yang berwawasan lingkungan dan berkelanjutan. Kotoran sapi merupakan bahan organik yang mempunyai prospek yang baik dijadikan pupuk organik (bokashi), karena mempunyai kandungan unsur hara yang cukup tinggi selanjutnya dijelaskan bahwa pupuk bokashi kotoran sapi merupakan salah satu alternatif dalam penerapan teknologi pertanian organik yang berwawasan lingkungan dan berkelanjutan.

Penggunaan bahan organik hingga saat ini dianggap sebagai upaya terbaik dalam perbaikan produktifitas tanah marginal termasuk tanah masam. Arinong (2005) menyatakan bahwa bahan organik berperan penting dalam meningkatkan kesuburan tanah melalui perbaikan sifat fisik, kimia, dan biologis tanah.

Menurut Noor dan Ningsih (2001), bokashi kotoran sapi merupakan pupuk lengkap, yang mengandung unsur hara makro dan mikro. Kandungan unsur hara bokashi kotoran sapi adalah Nitrogen ( $\mathrm{N}$ ) sebesar 0,92 \%, Posfor ( P ) 0,23\%, Kalium ( K ) 1,03\%, serta mengandung $\mathrm{Ca}, \mathrm{Mg}$, dan sejumlah unsur mikro lainnya seperti $\mathrm{Fe}, \mathrm{Cu}, \mathrm{Mn}, \mathrm{Zn}$, Bo, dan Mo, yang berfungsi sebagai bahan makanan bagi pertumbuhan dan perkembangan tanaman.

Menurut Tolla et al. (2007) Pemberian dosis bokashi yang berbeda pada tanaman jagung menunjukkan semakin tinggi dosis yang di berikan maka semakin bagus pula pertumbuhan dan produksinya. Dosis 20 ton/ha bokashi kotoran sapi memberikan hasil yang tertinggi pada pertumbuhan dan produksi tanaman jagung

Berdasarkan uraian diatas maka peneliti tertarik untuk melakukan 
penelitian level penambahan bokashi kotoran sapi terhadap pertumbuhan dan produksi pada panen pertama rumput raja (Pennisetum purpureophoides). Tujuan penelitian ini adalah mengetahui pengaruh pemberian bokashi kotoran sapi terhadap pertumbuhan dan produksi rumput raja (Pennisetum purpureophoides) pada panen pertama.

\section{MATERI DAN METODE}

Penelitian ini telah dilaksanakan di Kelurahan Sumber Harta Kecamatan Sumber Harta Kabupaten Musi Rawas, dengan ketinggian tempat $78 \mathrm{~m}$ dpl, waktu penelitian selama 2 bulan dimulai pada bulan Maret sampai Mei 2017.

Bahan-bahan yang digunakan dalam penelitian ini adalah rumput Raja, air, tanah ultisol, pupuk bokashi kotoran sapi, polybag ukuran $10 \mathrm{~kg}$, waring/striming. Alat yang digunakan meliputi cangkul, parang, cutter, meteran, neraca analitik, alat tulis, dan ember. Tempat penelitian dilahan dengan ukuran $600 \mathrm{~cm} \times 800 \mathrm{~cm}$, sebelum digunakan areal dibersihkan. Selanjutnya lokasi penelitian di pagar keliling dengan menggunakan waring/striming.

Media tanam yang digunakan adalah tanah ultisol yaitu tanah yang diambil sampai kedalaman 1,5 meter, tanah yang sudah siap kemudian dibersihkan dari sisasisa ranting dan daun. Tanah dimasukan ke dalam polybag ukuran $10 \mathrm{~kg}$ sampai penuh sebanyak 72 polybag.

Bibit yang digunakan adalah stek batang yang diambil dengan cara memotong batang rumput raja sekitar $5 \mathrm{~cm}$ dari permukaan tanah. Lalu batang dipotong setiap 3 ruas/buku untuk dijadikan bibit. Bibit berasal dari satu lokasi yang sama dan seragam.

\section{Aplikasi Pupuk Bokashi}

Aplikasi pupuk bokashi kotoran sapi dicampurkan pada setiap polybag berukuran $10 \mathrm{~kg}$ dan di aduk secara rata dengan tanah dengan dosis sesuai perlakuan. Adapun dosis bokashi kotoran sapi yang digunakan yaitu $50 \mathrm{~g}, 75 \mathrm{~g}, 100$ $\mathrm{g}, 125 \mathrm{~g}$, dan $150 \mathrm{~g}$ per polybag, serta kontrol (tanpa bokashi kotoran sapi).

Penanaman rumput raja dilakukan pada sore hari, sebelum stek ditanam terlebih dahulu media tanam disiram dengan air hingga lembab supaya mudah dalam proses penanaman. Penanaman dilakukan bersamaan, setiap polybag diisi sebanyak satu stek (batang) rumput raja yang seragam. Penanaman stek dilakukan dengan posisi miring $30^{\circ}$.

Selama penelitian dilakukan pemeliharaan yaitu dengan melakukan pembersihan gulma dan penyiraman. Pembersihan gulma akan selalu dilakukan baik yang tumbuh pada polybag maupun yang tumbuh disekitar polybag. Penyiraman dilakukan setiap hari pada pagi dan sore pada saat musim kemarau, dan apabila pada musim hujan tidak dilakukan penyiraman. Penelitian ini berakhir setelah tanaman berumur 60 hari setelah tanam. Pada akhir penelitian dilakukan pengamatan sesuai parameter perlakuan. Dalam penelitian ini akan diamati beberapa parameter yaitu :

\section{Tinggi Tanaman $(\mathrm{cm})$}

Pengukuran tinggi tanaman dilakukan dengan cara mengukur dari pangkal batang diatas permukaan tanah sampai titik tumbuh teratas. Pengukuran dilakukan diakhir penelitian.

\section{Jumlah Anakan (tunas)}

Penghitungan jumlah anakan dihitung semua anakan yang terbentuk. Penghitungan dilakukan diakhir penelitian. 


\section{Produksi Berat Segar (g)}

Penghitungan produksi berat segar dilakukan dengan cara menimbang tanaman rumput raja yang telah dipotong pada ketinggian $5 \mathrm{~cm}$ dari pangkal batang.

\section{Produksi Berat Kering (g)}

Produksi berat kering, setiap polybag tanaman rumput raja ditimbang berat keringnya, yaitu setelah tanaman dikeringkan dengan sinar matahari selama 48 jam.

\section{Produksi Bahan Kering (g)}

Tanaman yang sudah kering dari sinar matahari, kemudian dimasukan ke dalam oven dengan temperature $60^{\circ} \mathrm{C}$ selama 48 jam, selanjutnya dilakukan penimbangan.

\section{Rancangan Penelitian}

Penelitian ini menggunakan metode eksperimental dengan Rancangan Acak Kelompok (RAK) non faktorial terdiri dari 6 (enam) taraf perlakuan dan 4 (empat) kali ulangan sehingga didapat 24 unit percobaan dengan masing-masing 3 tanaman sampel, sehingga total sampel yang digunakan 72 unit tanaman rumput raja. Perlakuan yang akan dicobakan dalam penelitian ini adalah sebagai berikut:

P0 = Tanpa pupuk bokashi kotoran sapi (kontrol)

P1 = Pupuk Bokashi Kotoran Sapi dengan dosis 10 ton/Ha $=50 \mathrm{~g} /$ Polybag

P2 = Pupuk Bokashi Kotoran Sapi dengan dosis 15 ton/Ha $=75 \mathrm{~g} /$ Polybag

P3 = Pupuk Bokashi Kotoran Sapi dengan dosis 20 ton $/ \mathrm{Ha}=100 \mathrm{~g} /$ Polybag

P4 = Pupuk Bokashi Kotoran Sapi dengan dosis 25 ton $/ \mathrm{Ha}=125 \mathrm{~g} /$ Polybag.

P5 = Pupuk Bokashi Kotoran Sapi dengan dosis 30 ton $/ \mathrm{Ha}=150 \mathrm{~g} /$ Polybag.

Apabila perlakuan menunjukan pengaruh nyata sampai sangat nyata, maka di adakan uji lanjutan dengan menggunakan Uji Beda Nyata Jujur (BNJ)

\section{HASIL DAN PEMBAHASAN}

Hasil analisis keragaman pengaruh pemberian bokashi kotoran sapi terhadap pertumbuhan dan produksi rumput raja (Pennisetum purpureophoides) pada panen pertama tercantum pada Tabel 1.

Tabel 1. Pengaruh pemberian bokashi kotoran sapi terhadap pertumbuhan dan produksi rumput raja (Pennisetum purpureophoides) pada panen pertama

\begin{tabular}{llll}
\hline No & Peubah yang diamati & $\mathrm{P}$ & $\mathrm{KK}(\%)$ \\
\hline 1. & Tinggi Tanaman $(\mathrm{cm})$ & $22,10^{* * *}$ & 3,81 \\
2. & Jumblah Anakan (tunas) & $33,84^{* *}$ & 6,67 \\
3. & Produksi Berat Segar $(\mathrm{g})$ & $5,19^{* *}$ & 16,55 \\
4. & Produksi Berat Kering $(\mathrm{g})$ & $6,74^{* *}$ & 2,77 \\
5. & Produksi Bahan Kering(g) & $33,35^{* *}$ & 2,73 \\
\hline
\end{tabular}

Keterangan :

$\mathrm{P} \quad=$ Perlakuan Pemberian Bokashi Kotoran Sapi

$* * \quad=$ Berpengaruh sangat nyata

$\mathrm{KK}=$ Koefesien Keragaman 
Hasil analisis keragaman menunjukan bahwa perlakuan pemberian bokashi kotoran sapi berpengaruh sangat nyata terhadap tinggi tanaman, jumlah anakan, produksi berat segar, produksi berat kering dan produksi bahan kering.Hasil uji BNJ dan data tabulasi perlakuan bokashi kotoran sapi terhadap semua peubah yang diamati tercantum pada Tabel 2.

Tabel 2. Hasil uji BNJ perlakuan bokashi kotoran sapi dan data tabulasi pada semua peubah yang diamati

\begin{tabular}{|c|c|c|c|c|c|c|c|c|}
\hline \multirow{2}{*}{ Parameter yang diamati } & \multicolumn{6}{|c|}{ Perlakuan } & \multicolumn{2}{|c|}{ Nilai BNJ } \\
\hline & $\mathrm{P} 0$ & $\mathrm{P} 1$ & $\mathrm{P} 2$ & P3 & $\mathrm{P} 4$ & P5 & $5 \%$ & $1 \%$ \\
\hline Tinggi Tanaman $(\mathrm{cm})$ & $1.65^{\mathrm{aA}} \pm 12.80$ & $192,75^{\mathrm{bB}} \pm 3.43$ & $1.87^{\mathrm{bB}} \pm 10.24$ & $193.33^{\mathrm{bB}} \pm 17.55$ & $198.33^{\mathrm{bB}} \pm 8.97$ & $209.67^{c c} \pm 5.66$ & 16.6 & 20,29 \\
\hline Jumlah Anakan (tunas) & $5.17^{\mathrm{aA}} \pm 1.38$ & $5.83^{\mathrm{aA}} \pm 1.40$ & $6.25^{\mathrm{bA}} \pm 1.53$ & $6.83^{\mathrm{bB}} \pm 1.29$ & $7.75^{\mathrm{cB}} \pm 1.14$ & $8.75^{\mathrm{cC}} \pm 1.07$ & 1,01 & 1,26 \\
\hline Produksi Berat Segar (g) & $497.50^{\mathrm{aA}} \pm 1.38$ & $505.33^{\mathrm{bA}} \pm 1.40$ & $508.17^{\mathrm{cC}} \pm 1.53$ & $562.92^{\mathrm{CC}} \pm 1.29$ & $649.33^{\mathrm{cc}} \pm 1.14$ & $774.50^{\mathrm{dE}} \pm 1.07$ & 6,85 & 8,54 \\
\hline Produksi Berat Kering (g) & $328.50^{\mathrm{aA}} \pm 12.37$ & $331.50^{\mathrm{aA}} \pm 10.41$ & $337.25^{\mathrm{aA}} \pm 10.94$ & $343^{\mathrm{aA}} \pm 12.81$ & $352^{\mathrm{bA}} \pm 5.84$ & $360.50^{\mathrm{bB}} \pm 16.68$ & 21,30 & 26,56 \\
\hline Pruduksi Bahan Kering (g) & $31.25^{\mathrm{aA}} \pm 0.96$ & $32^{\mathrm{aA}} \pm 1.15$ & $34.25^{\mathrm{bB}} \pm 2.22$ & $34.75^{\mathrm{bB}} \pm 0.96$ & $36.25^{\mathrm{bB}} \pm 1.26$ & $38.75^{\mathrm{cC}} \pm 1.26$ & 2,11 & 2.63 \\
\hline
\end{tabular}

Keterangan : Angka - angka yang diikuti oleh huruf yang sama pada baris yang sama berarti berbeda tidak nyata pada taraf uji BNJ $5 \%$ dan $1 \%$.

\section{Tinggi Tanaman $(\mathbf{c m})$}

Hasil analisis keragaman menunjukan bahwa perlakuan level bokashi kotoran sapi berpengaruh sangat nyata $(\mathrm{P}<0,01)$ terhadap pertumbuhan tinggi tanaman hal ini terlihat perbedaan terhadap ratarata tinggi tanaman pada setiap perlakuan, dimana Kontrol (P0) menempati posisi terendah sedangkan yang tertinggi yaitu perlakuan yang diberi bokhasi $150 \mathrm{~g}$ (P5). Diketahui bahwa perlakuan P5 menghasilkan tinggi tanaman tertinggi yaitu dengan rata rata 209,67 $\mathrm{cm}$ dan terendah pada perlakuan P0 yaitu dengan rata rata $165,33 \mathrm{~cm}$. Rata-rata tinggi tanaman terlihat berurutan sesuai level yang diberikan, semakin tinggi level bokhasi kotoran sapi yang diberikan, semakin tinggi pula laju pertumbuhan tinggi tanaman.
Pemberian bokashi dengan dosis yang lebih banyak akan semakin memperbaiki kandungan unsur hara tanah. Hal ini sesuai dengan pendapat Hidayat (2003), menyatakan bahwa penggunaan pupuk dalam kegiatan budidaya dimaksudkan untuk meningkatkan ketersediaan hara dalam tanah bagi tanaman. Selanjutnya Sholeh et al., (1997), menyatakan bahwa penambahan bahan organik (bokashi) ke dalam tanah dapat meningkatkan kandungan bahan organik dan unsur hara dalam tanah.

Pemberian pupuk berkaitan erat denganketersediaan unsur hara essensial yang dibutuhkan oleh tanaman. Bokashi dapat meningkatkan dan memperbaiki kandungan unsur hara, ini disebabkan karena bokashi kotoran sapi mengandung bahan organik 
yang dapat meningkatkan kesuburan tanah. Selain itu bokashi juga mengandung unsur hara makro (N,P, dan $\mathrm{K}$ ) dan unsur hara mikro seperti $\mathrm{Ca}, \mathrm{Mg}, \mathrm{B}, \mathrm{S}$, dan lainnya. Unsur hara makro inilah yang dibutuhkan oleh tanaman. Peran utama nitrogen bagi tanaman adalah untuk merangsang pertumbuhan tanaman secara keseluruhan, khususnya batang, cabang dan daun. Nitrogen juga berperan penting dalam hal pembentukan hijau daun yang berguna sekali dalam fotosintesis (Lingga dan Marsono, 2003).

Demikian juga dengan phospor selain berperan dalam proses fotosintesis, phospor juga berperan dalam menstimulasi pertumbuhan akar, pembentukan benih dan respirasi. Hal ini sesuai dengan pendapat Winata (2012), Unsur hara yang dibutuhkan tanaman diperoleh dari tanah hasil dari dekomposisi bahan organik yang akan memperbaiki kesuburan fisik, kimia dan biologi tanah. Ketersediaan unsur hara tanah di daerah tropis tidak dapat mencukupi kebutuhan tanaman untuk pertumbuhan dan produksi, sehingga perlu penambahan pupuk sebagai sumber unsur hara.Terpenuhimya kebutuhan unsur hara makro inilah yang diduga menyebabkan adanya pengaruh level perlakuan pemupukan terhadap pertambahan tinggivertikal tanaman.

\section{Jumlah Anakan (Tunas)}

Hasil analisis keragaman menunjukan bahwa perlakuan level bokashi kotoran sapi berpengaruh sangat nyata $(\mathrm{P}<0,01)$ terhadap pertambahan jumlah anakan. Diketahui bahwa perlakuan P5 menghasilkan jumlah anakan terbanyak dengan rata rata 8,75 tunas dan paling sedikit pada perlakuan P0 yaitu dengan rata rata 5,17 buah. Hasil uji Beda Nyata Jujur (BNJ) menunjukkan bahwa pada perlakuan P5 (30 ton/ha) memberikan jumlah anakan yang terbanyak $(8,75$ anakan). Hal ini disebabkan karena bokashi yang berasal dari kotoran sapi mengandung sejumlah unsur hara dan bahan organik yang dapat memperbaiki sifat fisik, kimia dan bilogi tanah serta menyediakan unsur hara $\mathrm{N}, \mathrm{P}$ dan $\mathrm{K}$ yang dibutuhkan oleh tanaman. Penambahan bahan organik dalam bokashi yang semakin banyak maka semakin banyak pula unsur hara terutama unsur $\mathrm{N}$ yang diterima oleh tanah. Unsur $\mathrm{N}$ merupakan unsur hara yang penting karena merupakan unsur hara yang paling banyak dibutuhkanuntuk pertumbuhan tanaman. Nitrogen $(\mathrm{N})$ berfungsi sebagai penyusun asam-asam amino, protein komponen pigmen klorofilyang penting dalam proses fotosintesis.Sebaliknya jika kekurangan $\mathrm{N}$ menyebabkan pertumbuhan dan perkembangan tanaman terganggu yang disebabkan oleh terganggunya pembentukan klorofil yang sangat penting untuk proses fotosintesa (Sholeh et al.,1997).

\section{Produksi Berat Segar}

Hasil pengamatan jumlah berat segar menunjukan bahwa perlakuan pemberian bokashi kotoran sapi berpengaruh sangat nyata $(\mathrm{P}<0,01)$ terhadap produksi berat segar. Diketahui bahwa perlakuan P5 menghasilkan produksi berat segar tertinggi yaitu dengan rata rata 774,50 g dan paling sedikit pada perlakuan P0 yaitu dengan rata rata 497,50 g. Hal ini diduga berkaitan dengan peranan $\mathrm{N}$ sebagai komponen yang berperan bagi pertumbuhan tanaman.

Bertambahnya unsur $\mathrm{N}$ dalam tanah berasosiasi dengan pembentukan Sel-sel pada tanaman sehingga hal ini meningkatkan proses fotosintesis yang 
memacu pertumbuhan dan jumlah tanaman sehingga berpengaruh pada berat segar perlakuan. Peranan $\mathrm{P}$ sebagai komponen essensisl ADP dan ATP yang bersamasama berperan penting dalam fotosintesis dan penyerapan ion inilah yang diduga mampu meningkatkan produksi tanaman. Semakin lama umur tanaman akan memberikan kesempatan pada tanaman untuk tumbuh lebih lama sehingga jumlahdaun yang terbentuk pun lebih banyak dan berpengaruh pada berat segar tanaman. Selanjutnya Sutedjo (2010), menyatakan bahwa pemberian bokashi sebagai sumber bahan organik juga meningkatkan aktivitas mikroorganisme di dalam tanah.

\section{Produksi Berat Kering}

Hasil analisis keragaman menunjukan bahwa perlakuan pemberian bokashi kotoran sapi berpengaruh sangat nyata $(\mathrm{P}<0,01)$ terhadap produksi berat kering. Diketahui bahwa perlakuan P5 menghasilkan produksi berat kering tertinggi yaitu dengan rata rata 360,50 g dan paling sedikit pada perlakuan P0 yaitu dengan rata rata 328,50 g. Hal ini karena produksi berat kering dipengaruhi oleh produksi berat segar dimana pada perlakuan P5 juga menghasilkan produksi berat segar yang tertinggi sehingga berpengaruh pada produksi berat kering. Hal ini juga dipengaruhi oleh banyaknya jumlah daun ataupun anakan pada perlakuan P5 sehingga kemampuan fotosintesisnya lebih besar jika dibandingkan dengan perlakuan yang lain. Hal ini sesuai dengan pendapat Djunaedi (2009) bahwa produksi tanaman biasanya dipengaruhi oleh pertumbuhan vegetatifnya. Jika pertumbuhan vegetatifnya baik, maka ada kemungkinan produksinya akan baik pula.

\section{Produksi Bahan Kering}

Hasil analisis keragaman menunjukan bahwa perlakuan pemberian bokashi kotoran sapi berpengaruh sangat nyata terhadap bobot bahan kering. Diketahui bahwa perlakuan P5 menghasilkan bahan kering terbaik yaitu dengan rata rata $38,75 \mathrm{~g}$ dan paling sedikit pada perlakuan $\mathrm{P0}$ yaitu dengan rata rata 31,25 g. Pada perlakuan P5 menghasilkan bahan kering terbaik hal ini diduga karena pada pengamatan produksi berat segar dan produksi berat kering didapat pada perlakuan P5 yang terbaik dibandingkan pada perlakuan lainnya, hal ini juag berlaku pada perlakuan P0 dimana pada perlakuan P0 menghasilkan produksi terendah pada semua peubah yang diamati. Hal ini dikarenakan pupuk bokashi kotoran sapi mengandung unsur hara Makro dan Mikro (C, N, P, K, Ca dan Mg) yang berfungsi untuk proses pertumbuhan dan produksi. Sesuai dengan pendapat Tola et al. (2007) bahwa peningkatan pemberian bokashi pada level tertentu mampu memberikan pengaruh pada pertumbuhan dan produksi tanaman. Selanjutnya Arinong (2005) bahwa untuk meningkatkan pertumbuhan dan produksi tanaman, bila bokashi diaplikasikan ke tanah maka akan berfungsi sebagai media atau pakan untuk perkembangan mikroorganisme, sekaligus menambah unsur hara dalam tanah.

\section{KESIMPULAN}

Berdasarkan penelitian yang di lakukan dapat disimpulkan, bahwa: Perlakuan dosis pupuk bokashi kotoran sapi memberikan pengaruh sangat nyata pada semua peubah yang diamati dan Pemberian Pupuk Bokashi Kotoran Sapi dengan dosis 30 ton/Ha setara 150 
g/Polybag memberikan hasil terbaik pada semua peubah yang diamati yaitu: tinggi tanaman, jumlah anakan, produksi berat segar, produksi berat kering dan produksi bahan kering.

\section{DAFTAR PUSTAKA}

Arinong. 2005. Aplikasi Berbagai Pupuk Organik pada Tanaman Kedelai di Lahan Kering. Jurnal Sains dan Teknologi. 5 (2):65-72

Djunaedy, A. 2009. Pengaruh jenis dan dosis pupuk bokashi terhadap pertumbuhan dan hasil kacang panjang (Vigna sinensis L.). Agrovigor, 2(1): 42-46.

Fanindi, A.S. Yuhaini dan A.Wahyu 2005. Pertumbuhan dan produktifitas tanaman Sorgum (Sorgum bicolor L) Moeneh dan Sorgum sudanense (Piper Stafp) yang Mendapatkan Kombinasi Pemupukan N,P,K dan Ca. Prosiding Seminar Nasional Peternakan dan Veteriner, 12-13 September di Bogor, Buku 2 : 872885 .

Hidayat, M.F. 2003. Pemanfaatan Asam Humat dan Omega pada Pemberian Pupuk NPK terhadap Pertumbuhan Gmelina arborea Roxb yang Diinokulasi Cendawan Mikroba Arbuskular (CMA). Tesis. Program Pascasarjana. Institut Pertanian Bogor.

Gonggo, B. M., B. Hermawan, and D. Anggraeni. 2005. Pengaruh jenis tanaman penutup dan pengolakan tanah terhadap sifat fisika tanah pada lahan alang-alang. Jurnal ilmu-ilmu pertanian Indonesia. 7(1):44-55.

Lingga, P. dan Marsono. 2003. Membuat Kompos. Cetakan ke- Enam. PT. Swadaya. Jakarta.
Noor, A. dan R.D. Ningsih. 2001. Upaya meningkatkan kesuburan dan produktivitas tanah di lahan kering. Dalam. Prosiding Lokakarya Strategi Pembangunan Pertanian Wilayah Kalimantan. Instalasi Penelitian dan Pengkajian Teknologi Pertanian. Banjarbaru.

Suyitman, S. Jalaludin, Abudinar, N. Muis, Ifradi, N. Jamaran, M. Peto, dan Tanamasni. 2003. Agrostologi. Diktat. Fakultas Peternakan Universitas Andalas, Padang.

Sanderson, M. A. and R. A., Paul. 2008. Perennial forages as second generation bioenergy crops. International Journal of Molecular Sciences. 9: 768-788.

Sholeh, D. Nursyamsi, S. J. Adiningsih. 1997. Pengolahan bahan organik dan Nitrogen untuk tanaman padi dan ketela pohon pada lahan kering yang mempunyai tanah ultisol di Lampung. Prosiding: Pertemuan pembahasan dan komunikasi hasil penelitian tanah dan agroklimat, Bidang Kimia dan biologi tanah, Depertemen Pertanian. Pp: 193-206.

Sutedjo, M. M. 2010. Pupuk dan Cara Pemupukan. Rineka Cipta, Jakarta.

Tola, F. H. dan K. Dahlan. 2007. Pengaruh Penggunaan Dosis Pupuk Bokashi Kotoran Sapi terhadap Pertumbuhan dan Produksi Tanaman Jagung. Jurnal Agrisistem, 1(3): 3043.

Winata, N. A. S. H., Karno, K., dan S. Sutarno. 2012. Pertumbuhan dan Produksi Hijauan Gamal (Gliricidia sepium) dengan Berbagai Dosis Pupuk Organik Cair. Animal Agriculture Journal. 1(1): 797-807. 